\title{
Styring og lederskab er skabt af mennesker og rettet mod menneskers adfærd
}

\author{
Af Preben Melander *)
}

\section{A. Indledning}

\section{Det politiserede mediesamfund}

Vort samfund og dets udviklings- og styringsvilkår ændrer sig dramatisk i disse år. Dette gælder både socialt, politisk, kulturelt og økonomisk. At producere en opdateret og relevant vidensamling inden for styring og lederskab er en svær opgave, fordi vort videngrundlag om samfundets og lederes grundlæggende arbejdsvilkår er begrænset og under konstant forandring. Dertil kommer, at vore medier er under socialt og politisk pres. Konstrueret misinformation kaldet "fake news" spredes overalt, og det forvirrer menneskers tillid til, hvad der er sandt og falsk, og hvad der er godt og dårligt. Videnskaben overdøves af mediernes malstrøm af misinformation, vildledninger og spredning af konspirationsteorier. Denne vildledning er skabt af mennesker, der ud fra bevidste politiske, kommercielle og egocentrerede motiver ser det som sin mission at påvirke samfundets udvikling og meningsdannelse i en bestemt for dem selv gunstig retning. Vi har således fået et politisk og populistisk mediesamfund, hvor politikerne går mere op i at ensrette borgernes meningsdannelse end at skabe et balanceret og værdibaseret retssamfund.

Vi ser her i et alvorligt samfundsproblem, der er til fare for vores demokrati, vores sociale frihed og tilliden til det politiske system. Set i dette lys er det vigtigt, at vore beslutningstagere herunder politikerne forholder sig kritisk og realistisk til, hvad styring og lederskab betyder for et samfund.

\section{Den lukkede og ensidige debat om fremtidens styringsformer og lederskabsideer}

Set i dette samfundsperspektiv er det oplagt at skabe forståelse for udviklingen og perspektiverne for fremtidens styringsformer og ledelsesmodeller. Er vi i stand til at skabe og sikre åbne og fleksible vilkår for udviklingen af samfundsrelevante og menneskebårne styrings- og ledelsesformer?

\footnotetext{
*) Preben Melander er professor emeritus og ansvarshavende redaktør for Samfundslederskab i Skandinavien.
} 
Det største problem er her, at vi over tid har skabt nogle faste og konservative forestillinger om, at styrings- og ledelsesmodeller har til formål at skabe stabile strukturer og orden, og at dette bedst kan opnås ved at indføre økonomiske procedurer og rationelle rutiner. Derved bliver styringen meget mekanistisk, som ikke kan trække på menneskers kritiske sans og kreativitet. Mennesker eksisterer reelt ikke i dette klassiske styringsperspektiv, som faktisk har været toneangivende i de sidste 60 år. Mennesker er her blot objekter, som vi med rationel teknologi kan måle, beskrive og holde regnskab med til gavn for systemets overlevelse.

Et andet problem er, at vi ofte går ud fra, at organisationer har de samme styringsproblemer og kan anvende de samme styringsmodeller og procedurer, som styringsfolket anbefaler. Heri ligger, at alle styringsideer centrerer sig om det, som kan udtrykkes i økonomiske termer, dvs. især i tal. Det betyder, at styring begrænser sig til stereotype målinger og beskrivelser, som styringssamfundet har institutionaliseret som legale normer, og som ikke giver et korrekt billede af virkeligheden. Et godt eksempel er de udbredte målinger af elevers læring i folkeskolen.

Et tredje problem ligger i, at stort set alle styringsmodeller og ledelsesideer tager afsæt i, at styringsfolket ser styringsprocesser som startende oppefra. Styringsbeslutninger træffes derfor ofte fra centralt hold og nedbrydes derefter ned gennem hierarkiet. Dette forhold vil ofte låse beslutninger fast i bestemte strukturer, der i praksis vil vanskeliggøre styringskoordination på tværs af organisationen.

Alle de her nævnte styringsproblemer er afledt af vores teoretiske bindinger til gamle myter og forestillinger, som ledere og medarbejdere forventes at leve med. Det vil naturligvis resultere i en daglig modstand mod de indførte økonomisystemer. Konsekvenserne heraf, tager vi op i det efterfølgende nummer af SIS. 